\title{
AN APPROACH TO A SYSTEM OF "PERFECT" MUNICIPAL TAX COLLECTIONS
}

\author{
RAYMOND M. GREER*
}

During the periods of prosperity, when most people in the property-owning class have more money than their actual needs, they take very little, if any, interest in the cost of government and, incidentally, the taxes levied against them to cover such cost. As a result, the property owners are often tempted to use tax monies for speculative purposes because they believe they will receive a return greater than the tax penalty. In other words, they use their tax monies to finance speculations. They pay little attention to the increased cost of government which nearly always comes about during periods of prosperity. However, economic history shows one depression after another between periods of prosperity. The present depression, more severe than any other in our memory, has emphasized more forcibly than ever before many things relative to the levy and collection of taxes and the cost of government.

Partial blame for the inertia of the taxpayers must be laid at the door of those municipalities which have failed to keep the taxpayers tax-conscious at all times. During the periods of prosperity local governments share in obtaining easy money. They have very little trouble in borrowing in anticipation of the future collection of delinquent taxes. Therefore, lacking the need for rigid tax collection methods, they naturally follow the line of least resistance and borrow in anticipation of the collection of taxes rather than resort to the more or less disagreeable task of forcing tax collections by using all the powers within their means.

Now, then, let us see what happens during this period. To reiterate, the taxpayer takes little interest in his tax bill as he is not forced to pay his taxes. The municipality, having easy avenues of credit, does not force the tax collections but resorts to financing a substantial portion of its budget with borrowed money. The longer the period of prosperity, the more precarious becomes the position of both the taxpayer and the municipality. If, for instance, the period of prosperity extends over eight

- Comptroller of Jersey City, New Jersey. - Master in Chancery of New Jersey. Certified Public Accountant, New York and New Jersey; Registered Municipal Accountant, New Jersey. Member of the firm of Boyce, Hughes \& Farrell, Certified Public Accountants, New York City. Member of New York State Society of Certified Public Accountants; New Jersey State Society of Certified Public Accountants; American Society of Certified Public Accountants. Instructor of Municipal Accounting and Finance, Newark Institute of Arts and Sciences. Member of the Committee on a Model Tax Collection Law of the National Municipal League. 
years and suddenly a depression comes about, the taxpayer finds himself owing, perhaps, five years' taxes which he could have paid in a majority of cases. The municipality finds itself with a top-heavy burden of floating indebtedness created, largely, through financing itself on borrowed money in anticipation of the collection of delinquent taxes which it has often made little effort to collect. The taxpayer's income from which he must pay taxes is suddenly severely curtailed and often entirely eliminated. The avenues of easy credit are suddenly closed to the municipality. It can no longer borrow but must either repay the monies previously borrowed during the period of prosperity or face the only other alternative, default. With the bugaboo of default appearing on the horizon, the first impulse is to inflate the budget to meke up the slack in cash collections. Payrolls and debt service payments become uncertain.

Immediately, the defects of this system are brought to the front. Experts bloom overnight and are employed to study the situation and devise ways and means of remedying it. Organizations are formed, the Chamber of Commerce.and other civic bodies immediately create committees, as does the legislature, to study the tax problem. Out of all this come various ideas for the creation of more rigid methods of tax collection, and more rigid functioning of municipal powers to collect such delinquent taxes. Taxing authorities and taxpayers become suddenly and painfully tax-conscious. Various efforts are immediately made to slam shut the "stable door" with the taxpayer desperately attempting to hold it open until he can sell the "horse." All sorts of improved methods are suggested, all of which are good if they can be made to work. There are usually a few vital factors overlooked, chief among which is the method of approaching a system of "perfect" tax collections. Sins of omission in the tax collecting business are difficult of atonement.

As we have said before, we find ourselves at the end of a period of prosperity and the beginning of a depression with the taxpayer owing a number of years' taxes and the municipality desperately in need of funds. Rigid tax collection methods and laws cannot now be practically applied, first, because the taxpayer has not enough money to pay up all of his tax liens; and, second, the municipality's confiscation of his property will, in a majority of cases, not produce immediate cash. One may talk with great force about taxes being a first lien and about municipal powers to collect taxes, but, if the money is not available, a way must be found of solving the problem without causing the conscientious taxpayer to lose his property and without forcing the municipality to fall into hopeless default.

We now approach the necessary steps to put our house in order and to permit, after the completion of these steps, the "perfect" tax collection method. These steps will naturally differ according to varying situations arising in the taxing districts. Some districts will have peculiar problems which arise because of the physical make-up of the municipality and the degree of enforcement of tax collection laws. 
Before any intelligent steps can be taken the tax delinquencies should be classified into, chiefly, the following classes:

One and two-family houses.

Tenement houses (i.e. multi-family houses of the older and unimproved type).

Modern apartment houses, hotels, clubs, etc.

Stores and other small commercial properties..

Factories and large industrial properties.

Vacant land.

The reason for segregating these delinquencies is that different methods of forcing the payment of delinquent taxes should be applied, depending upon the class in which the property falls.

Obviously, more leniency should be shown to the small home owner, first, because, comparatively, his income is less; and, second, the loss of his home so demoralizes him that very often we find him and his family listed upon the relief rolls, and correspondingly increasing the tax burden. Experience has definitely shown that this class of property owner makes every possible effort to pay taxes and preserve his home, when pressed to do so.

More time must also be given the tenement and poor class multi-family houses, as the income to owners of this type of property is always proportionately less, particularly so during times of depression. The people who rent these houses have no reserve of funds and are the first to double-up. As a result, more vacancies in that class of property are created proportionately.

Commercial and industrial properties are a problem which must be treated separately, depending upon their location, the type of industry and commerce, and the extent to which they have felt the depression.

Vacant land should be given the least consideration, as most always it contributes little, if anything, economically to the municipality and is very often held in speculation. Most certainly, such speculation should not be financed by the municipality by permitting large tax delinquencies to continue, even if tax enforcement means confiscation of the property.

Please keep in mind that in giving the following suggestions for the approach to a "perfect" tax collection system we realize that it will undoubtedly be necessary for the legislatures to enact amendments to the tax collection laws permitting the application of these suggestions for a period long enough to correct the condition brought about by the inertia of the taxpayer and the tax collector.

A form of notice should be prepared and sent to the small home owner pointing out to him the fact that he is delinquent in his tax payments and also the necessity for the municipality to collect the delinquencies, together with the fact that in the near future the municipality will hold a tax sale. It is necessary to mention this or some other drastic threat in order to impress upon the taxpayer the necessity of doing something about his tax delinquencies, if possible. The notice should be in the form 
of an invitation rather than a demand. The taxpayer should be invited to appear at the tax collector's office to discuss his problem with municipal officials. The interviewing should be done at night in order that the taxpayer will not lose a day's pay to attend this conference. This work of interviewing the taxpayer should not be left to clerks whose tact and judgment in handling the situation is apt not to be the best, but should be undertaken by officials. Such treatment is appreciated by the taxpayer and is more impressive. The taxpayer should be invited to sit down and work out a method of paying his taxes which will be within his means. The officials interviewing the taxpayers will hear the same hard-luck stories thousands of times but should appear interested, and not bored, by such repetition, as each delinquent taxpayer feels as though he has a special problem. If he is accorded sympathetic treatment we know from experience that he will do everything in his power to save his home.

An instalment payment arrangement should be made with each taxpayer, its stringency depending upon his income and the type of property. It is foolish to extract a promise from him to pay more than he is able, as, obviously, he will fall down on his agreement and become further discouraged. This agreement should include a promise from the taxpayer to pay his current taxes when due, and allow him a reasonable time in which to pay his delinquencies, on a monthly basis. In order to give him some inducement to do his utmost to pay, interest penalties should be suspended on the arrears so long as his agreement to pay is faithfully kept. Upon his failure to keep his agreement, interest penalties should not only again commence to accrue, but penalties so suspended should be added, and the whole tax become due and subject to a tax sale. While such agreement is in force the taxpayer will be assured of his property being excluded from future tax sales. As has been previously 'pointed out, the stringency of the agreement should vary according to the type of property and the tax-paying ability of the owner. Arrearages should be cleaned up according to the peculiar circumstances of the individual. Once the taxpayer has saved his property from a tax sale he will strain his resources to keep up his instalment payments as in so doing he saves a considerable amount in interest penalties as they have stopped accruing from the date of his agreement and for as long as it is kept.

Now, at this point, let us see what we have accomplished. We have some assurance of current taxes being paid when due. This is a great step forward to "perfect" tax collections and will permit the municipality, in so far as this class of property is concerned, to meet its operating budgetary expenditures when due. As far as the arrears are concerned they have been largely borrowed against, and the holders of the tax anticipation paper will be more apt to extend the payment of these obligations, rather than force the municipality into default, if they can be assured that proper steps have been taken to collect these tax delinquencies and apply them against their loans. Obviously, forced default imperils the payment of these obligations more than an extension of the obligation, provided that an intelligent method of protecting 
the principal has been assured, within some reasonable length of time beyond its original due date. Debt readjustments have, as a consequence, become common occurrences.

An adequate follow-up system immediately becomes necessary. The taxpayer who has made an agreement must be taught that each instalment, preferably monthly, has to be met the same as the monthly gas or electric bill. It must be instilled in his mind that a default will result in the loss of his property at the next annual tax sale because of his breaking faith with the municipality. When a payment is missed, the owner should be immediately notified—or "reminded." The next notice should be a peremptory demand for payment. While such methods may seem to harass the taxpayer, they are essential in that they compel him to include tax payments in his budget for living expenses in the same manner as if they were rent payments. It has been discovered in many cases that the mortgagee is willing to reduce or suspend his mortgage interest in consideration of the leniency of the municipality in keeping the property out of a tax sale, as long as there is assurance that the tax instalment payments agreed upon will be kept up and will eventually clear up the indebtedness prior to his lien.

The modern apartment houses, hotels, clubs, etc., should be immediately forced into payment by their inclusion in a tax sale. This may seem a little hard on this class of property but it is the only thing that can be done. These properties are usually owned by people who are either speculating in potential values or they are investing for income. They usually carry a large first mortgage and very often a second mortgage. On account of the size of the mortgage the first mortgagee is usually a bank, insurance company, or other large investor who specializes in mortgage loans. Hence the mortgagee will usually have the ability to pay. Obviously, the municipality must collect large sums of money from tax delinquencies in order to put its own financial house in order. While it is expedient to give time to pay to the smaller taxpayer, the municipality must show to its creditors some evidence of financial stability. Taxes, of course, are a first lien coming before mortgages or any other liens upon property. They must be paid eventually; there is no escape. These delinquencies usually carry a higher rate of interest than the cost of mortgage money. Logically, it is to the best interest of the mortgagee to be forced, if necessary, to pay taxes and forego income upon his investment, at least temporarily. If these delinquencies are permitted to pile up, naturally the equity of the owner is seriously impaired, if not entirely wiped out, and the mortgagee, in order to protect his investment, must ultimately foreclose and take title to the property. Upon taking title to the property he is then liable for the payment of all the delinquent taxes which have been permitted to accrue, together with the payment of interest on such tax delinquencies.

If this line of reasoning is properly brought to the attention of not only the owner of the property but the mortgagee, they should be able to see its advantages. The 
least that it will do will be to force them to a decision. They will have to decide to pay the taxes and retain the property, sell it, or transfer the property to stronger hands which will be able to pay the current and delinquent taxes, since they acquire the property fully aware of this condition. In fact, they would not be willing to take the property over unless they were able to meet the tax payments. Unless a municipality has been more lax in permitting delinquencies than any which have come to my attention, by threatening a tax sale it does not take the chance of being forced to buy in this type of property itself. The amount due will be paid by either the owner or mortgagee, or purchased for the taxes by an outside purchaser, in the event of a tax sale. This type of property, being of the more readily salable class and having a depressed market price far in excess of the delinquent taxes, makes an attractive purchase in a tax sale. In the final analysis one of two things happens. Either the taxes are paid in full or the property is forced into stronger hands and thereby the payment of the delinquent and current taxes by the new purchaser is assured the municipality.

Very often stores and small commercial properties are in a more or less seasonal income class and, by reason of the fact that they are commercially small, they have not, as a rule, the business ability to budget their expenses and to create a reserve out of their seasonal peaks to finance the fluctuation in their income properly. As a result, this class of property finds itself in a depression almost hopelessly sunk when large tax delinquencies have been permitted to accrue, unless some intelligent, sympathetic treatment of its tax problem is offered it. While it is true that this class of property is usually mortgaged, very often the mortgagee is not strong enough, if a wholesale confiscation is attempted through a tax sale.

Those properties on which the mortgages are held by the same type of mortgagee. referred to in the apartment house and hotel class should be treated in the same manner as prescribed for that class, relentlessly forcing collections or forcing the properties into stronger hands. Such treatment may seem drastic, but as the taxes must be collected somehow, those who have the most valuable holdings and the best taxpaying ability will be the first to suffer.

Therefore, it again becomes largely an individual treatment regarding tax delinquencies. The very small store and factory, whose owner and mortgagee are financially weak, -should be given time to pay, based on an instalment plan, as referred to before, worked out on a basis of either ability to pay or income from the property or business, or both. This method of treatment of this class of property is not based entirely upon the big-heartedness of the municipal officials, but good business for their financial department. As large collections of delinquencies are necessary for financial restoration, a strong hand must be used wherever possible. Also, where a tax collector, from his long experience, believes that the property will fall into the hands. of the municipality through a tax sale, it is far better to show some leniency to the taxpayer and give him time to pay, based upon his income. 
In permitting such partial payments, the municipality immediately gets some income towards delinquencies and assures the collection of current taxes which is, of course, the paramount feature of the agreement. In addition, the municipality helps to preserve a going business, and, naturally, we all hope for better times and consequently better natural tax collections. If economic conditions continue to get worse and never improve, then no tax collection, system, no matter how strict, will be successful.

If the municipality disregarded these factors and held a tax sale based upon the figures as shown by its books and not upon intelligent treatment of the subject, it would find itself purchasing a large number of pieces of property which would have no immediate sale value. Most states permit a redemption period in their tax sale lawws, averaging from two years upwards. During this period, the original owner, in most cases, is permitted to retain possession of the property or sell it, and cannot be forced to pay anything during that period. At the end of the redemption period the municipality may foreclose its lien. Under most state laws, foreclosure proceedings not only take a great deal of time, but are cumbersome and expensive, and very often a title so obtained is not considered the best by any means. Some title companies refuse to insure the titles on properties foreclosed through tax sale procedure. Obviously, wholesale purchases of property in a tax sale are not desirable. This, of course, only applies to municipalities which have not held tax sales with any degree of regularity and have permitted huge sums of tax delinquencies to accumulate.

Factories and large industrial properties are not generally in the tax delinquent class to any great degree. If they are large commercially, it is obvious that when their financial position gets to such a state that they cannot pay their taxes, they are bankrupt and not true going concerns. In most cases there are so many people vitally interested in these properties that if the present management cannot succeed they are taken over and re-financed before it is necessary for the municipal officials to take drastic action. With this class of property one of two things happens. Either there is enough value left in them to make the payment of taxes possible, or the properties are wholly abandoned. It is only in the minority of cases that such properties are abandoned. When, however, the latter occurs there is nothing the municipality can do, if it has permitted large delinquencies to accrue, except sell the property in a tax sale; buy it in; perfect title; sell it at an absolute sale and take the loss.

Vacant land should ordinarily be given little or no consideration whatsoever in any plan devised to approach a strict tax collection system. It produces no improvement assessments so, therefore, wiithout having some very excellent reason for permitting instalment payments, and then only where it is manifestly to the advantage of the municipality, this class of property should be included in a tax sale. If the marketable value is equal or greater than the tax liens, an outside purchaser will bid it in at the tax sale where the owner or mortgagee is unable to do so. If the 
marketable value is less than the liens, the municipality will have to buy it in and sell it at an absolute sale for whatever price it will bring, even though it is necessary for the municipality to take a substantial loss. The reason for doing so is that the property is put back into the tax-paying class, and very often the building of improvements upon the land is encouraged because of the low sales price. The amount of ratables so gained may not only offset the loss in the lowered assessed value of the land, but, over a period of time, may more than offset the loss the municipality has taken through its absolute sale.

The so-called receivership method of tax collection ${ }^{1}$ is a useful and alternative means to be applied at least partially to the following classes of property: tenement houses; stores and small commercial property; and, in some cases, modern apartments, hotels, clubs, etc., where it is good judgment to do so.

Several states have very successfully applied a special form of receivership to the managing of income-producing properties. The best examples of this are its application in the states of Illinois and New Jersey. The municipalities in these states which took advantage of the receivership method collected many millions of dollars during this depression that they otherwise would not have collected within the same period of time. This method is applied in cases where the owner and the mortgagee refuse to coöperate with the local officials in the tax delinquency problem, and where a tax sale could not immediately be held, especially as it applies to properties which the municipal officials believe are good tax sale properties, (i.e. properties which are delinquent in tax payments, yet very attractive in the present real estate market and assured of an immediate buyer in a tax sale).

Although the receivership method may seem to present a complicated and almost impossible task, it has been tried and its success definitely proven. The delinquent taxes on many thousands of pieces of property have been collected in the application of this special form of receivership. This method, of course, eventually exhausts itself, but it will be found to be of great value in that interim leading up to the point where a "perfect" tax collection system can be applied.

I want also to point out that the threat of the application of receivership has been proven to be very effective in the stimulation of the collection of tax delinquencies. The word "receivership" is greatly feared by the owner and highly respected by the mortgagee. Naturally, in working out an instalment method of payment of taxes it is very often necessary to have a club, or some legal persuasion.

No excuse is being made here for the contribution of the tax collector and other municipal officials to the tax delinquent condition in which a great many municipalities now find themselves. However, when this condition does exist either they, or someone else, will have to recognize the problems and treat them intelligently, taking into consideration not only the factors contributing to this condition, but methods of correction.

\footnotetext{
${ }^{2}$ For a more extended discussion of this method, see De Long and O'Brien, Tax Receiverships, supra, p. 382 .
} 
It should be clearly understood that this article is not intended to set forth a "perfect" tax collection system, but merely to provide some of the steps necessary to be taken by municipalities, lax in tax enforcement, before any strict tax collection system can be made workable. Students of taxation have advocated many important changes in our tax collection systems, and if these steps were taken most of our tax collection problems would be solved. However, more modern methods of accounting should be installed and municipalities should attempt to obtain scientific, analytical analyses and statistical information which will keep them in more constant touch with changing conditions and local tax problems. As modern commercial business firms have found that it is necessary, especially today, to remind debtors constantly of their obligations, so the municipalities should benefit by their experience and install the modern dunning and follow-up collections systems suggested above.

Many hundreds of other suggestions have been made. A great many of them are constructive and necessary but, in my opinion, none of these suggestions. will work without first having put our municipal financial affairs in order, particularly as they concern tax delinquencies and outstanding obligations created by the borrowing against these delinquencies. Such steps are a prerequisite to the attainment of perfection in the collection of taxes. 